\title{
O DEVIDO PROCESSO LEGAL
}

THE DUE LEGAL PROCESS

Rubens Alexandre Elias Calixto ${ }^{1}$

ISSUE DOI: 10.21207/1983.4225.344

\section{RESUMO}

O princípio do devido processo legal apresenta-se como um dos pilares do Estado de Direito. Evocado com frequência na literatura jurídica e nas lides forenses, nem sempre é conhecido em toda a sua profundidade. Conhecê-lo a fundo exige o estudo da sua origem, evolução, significado, pressupostos e funções. Desde a sua primeira manifestação, na Magna Carta de 1.215, tornou-se um símbolo e uma referência no que diz respeito às garantias individuais e limites estabelecidos ao poder estatal. Suas feições atuais, porém, resultam de lenta evolução. No curso da história, foi mencionado em diversos textos de índole constitucional do Direito Inglês. Mas foi no Direito Norte-Americano que conheceu seu grande florescimento, não apenas através de emendas à Constituição dos EUA, mas também por meio de profícua elaboração jurisprudencial pela $\mathrm{Su}$ prema Corte daquele país, que veio a influenciar diversos sistemas constitucionais, inclusive o regime inaugurado pela Constituição Brasileira de 1988. Sua importância é inquestionável. Mas sua compreensão nem sempre é completa. Visando contribuir para seu melhor dimensionamento, este estudo traça seu perfil histórico e jurídico. Busca-se abordar sua origem, desenvolvimento, pressupostos, funções e significados.

Palavras-Chave: Devido processo legal. Origem. Evolução. Pressupostos. Funções. Significados.

1 Possui doutorado em Direito pela Pontifícia Universidade Católica de São Paulo, PUC/SP (2010). Possui mestrado em Direito pela Universidade Estadual Paulista Júlio de Mesquita Filho (2002). Atualmente é Professor da Faculdade de Direito de Franca. 


\section{ABSTRACT}

The principle of due process is one of the pillars of the rule of law. Often invoked in legal literature and forensic litigation, it is not always known in all its depth. Knowing it in depth requires the study of its origin, evolution, meaning, assumptions and functions. Since its first manifestation, in the Magna Carta of 1,215, it has become a symbol and a reference to the individual guarantees and limits established to state power. Its current features, however, result from slow evolution. In the course of history, it has been mentioned in several texts of a constitutional nature of English Law. But it was in American law that it flourished, not only through amendments to the US Constitution, but also through profitable jurisprudential elaboration by the Supreme Court of that country, which came to influence various constitutional systems, including the regime inaugurated by the United States. Brazilian Constitution of 1988. Its importance is unquestionable. But his understanding is not always complete. In order to contribute to its better dimensioning, this study traces its historical and legal profile. It seeks to address its origin, development, assumptions, functions and meanings.

Keywords: Due process. Source. Evolution. Assumptions. Functions. Meanings.

\section{INTRODUÇÃO}

O mundo ocidental assistiu, nas últimas décadas, a um substancial avanço dos regimes democráticos, acentuadamente no Leste Europeu e na América Latina, com a consequente proclamação do Estado de Direito, que confere protagonismo constitucional às garantias fundamentais do cidadão, com a correlata imposição de limites ao poder estatal.

Algumas dessas garantias são de natureza processual e corporificam o que alguns denominam direito processual constitucional, no qual se destaca o princípio do devido processo legal, regra matriz de um sistema de proteção da cidadania.

Há mais de cem anos declarado na Quinta e na Décima-Quarta emendas à Constituição Norte-Americana, esse princípio está também inscrito no inciso LIV do art. $5^{\circ}$ da Constituição Brasileira de 1988, sendo 
invocado com bastante frequência nas lides judiciárias e na literatura jurídica.

Trata-se de um dos conceitos jurídicos mais ricos em significado e conteúdo, que só podem ter boa compreensão se precedidos da análise histórica e política da sua origem e desenvolvimento.

Conhecê-lo a fundo, portanto, não é tarefa tão simples. Demanda estudo metódico e cuidadoso.

Existem dificuldades, a começar pela definição do devido processo legal, um desafio que nem mesmo a Suprema Corte norteamericana ousou enfrentar (Twining v. New Jersey; Holden v. Hardy; Solesbee v. Balkcom), conforme anotam Nelson Nery Junior ${ }^{2}$, Paulo Fernando Silveira ${ }^{3}$ e Adhemar Ferreira Maciel ${ }^{4}$.

Não obstante, há certo consenso de que o due process of law carrega a ideia de que todos os litigantes têm direito a um processo justo, não apenas na forma, mas, sublinhe-se, também no conteúdo.

Esta ideia conduz, inevitavelmente, a um problema axiológico, já que a própria noção de justiça é de cambiante valoração, conforme discorreu Hans Kelsen na clássica obra "O que é justiça?".

Isso explica porque muitos se esquivam de buscar a definição do devido processo legal, pois é difícil traçar os elementos essenciais de uma ideia que nada tem de fossilizada, estável e perene. Ao contrário, assim como a noção de justiça, o devido processo legal está permanentemente exposto às vicissitudes históricas, políticas e científicas da sociedade humana, às quais deve ser constantemente adaptado, para que continue cumprindo fielmente o seu papel.

Nesse contexto, é imperioso acentuar o sentido substantivo do devido processo legal, para que ele não seja reduzido à sua acepção puramente procedimental, equívoco comum e que ofusca o seu denso conteúdo ético-político.

Este é o objetivo do presente estudo, que não ignora os muitos obstáculos oferecidos pelo tema, mas que o enfrenta com a convicção de

\footnotetext{
${ }^{2}$ NERY JUNIOR, Nelson. Princípios do processo civil na Constituição Federal. 3. ed. rev. e aum. São Paulo: Revista dos Tribunais, 1996. (Coleção estudos de direito de processo Enrico Tullio Liebman; v. 21). p. 39.

${ }^{3}$ SILVEIRA, Paulo Fernando. Devido processo legal. 3. ed. rev., atual. e ampl. Belo Horizonte: Del Rey, 2001. p. 239.

${ }^{4}$ MACIEL, Adhemar Ferreira. Due process of law. Informativo Jurídico da Biblioteca Ministro Oscar Saraiva, v. 6, n. 2. 1994. p. 85.
} 
que o due process of law não pode ser convertido em um simples bordão jurídico e somente poderá ser razoavelmente compreendido mediante a abordagem da sua origem, pressupostos, funções e acepções.

\section{ORIGEM E DESENVOLVIMENTO DO DEVIDO PROCESSO LEGAL}

\subsection{ORIGEM}

A melhor compreensão do devido processo legal passa, necessariamente, pela pesquisa da sua origem e das circunstâncias históricas que motivaram o seu aparecimento.

Quase todos indicam a Magna Carta de 1215, do Rei João Sem Terra, da Inglaterra, como documento que, pela primeira vez, trouxe a ideia do devido processo legal, sob a denominação latina per legem terrae - no inglês, law of the land (lei da terra ou lei do país).

Não obstante, há entendimento diverso de Ruitemberg Nunes Pereira $^{5}$, o qual, amparado em obra de William Stubbs (Germany in the early middle ages), entre outros, sustenta que os primeiros traços do princípio estão num decreto do ano 1037 d.C., expedido pelo imperador germânico Conrado II, soberano do Sacro Império Romano-Germânico, durante expedição a Milão.

Pereira sustenta que Conrado II, fundador da Dinastia Franca, tinha a pretensão de instituir uma administração forte e estruturada para alcançar maior estabilidade política no Império, para o que seria fundamental regulamentar a transmissão da propriedade dos condes e vassalos.

Numa de suas expedições a Milão, em maio de 1037, Conrado II expediu decreto que reduziu a escrito o direito feudal e as práticas relativas à transmissão da propriedade, sendo que algumas disposições eram dotadas de caráter universal, "revelando-se, de fato, lídima positivação de valores sociais mais amplos, tangenciando, mui proximamente, o ideal de justiça no âmbito das relações privadas".

\footnotetext{
5 PEREIRA, Ruitemberg Nunes. O princípio do devido processo legal substantivo. Rio de Janeiro: Renovar, 2005. p. 5-26.
} 
Tal decreto conteria quatro normas fundamentais, sendo que, no entender de Pereira, merece destaque a primeira delas:

Segundo a primeira ordenança do Imperador, nenhum homem seria privado de um feudo sob o domínio do Imperador ou de um senhor feudal (mesne lord), senão pelas leis do Império (laws of empire) e pelo julgamento de seus pares (judgment of his peers), expressões que, reitere-se, foram escritas em 1037, e que, segundo STUBBS, foram simplesmente copiadas na Carta Magna Inglesa de 1215 (conforme veremos). ${ }^{6}$

Assim, no entender do sobredito autor, estariam lançadas as verdadeiras bases daquilo que, algum tempo depois, seria conhecido como devido processo legal.

Seu gérmen estaria na expressão laws of the empire, que guardaria semelhança com a expressão inglesa law of the land.

Não obstante os sólidos fundamentos da tese esposada por Ruitemberg Nunes Pereira, a doutrina majoritária entende que as sementes do devido processo legal são encontradas no édito do Rei João Sem Terra.

Segundo Arturo Hoyos ${ }^{7}$, parece existir acordo em que a Magna Carta, constituída originalmente de 63 capítulos e redigida em latim outrora o idioma oficial dos meios cultos e intelectuais da Inglaterra -, é a fonte original do devido processo legal, ainda que sob outra denominação.

Nelson Nery Junior ${ }^{8}$ sublinha que a Magna Carta não mencionava expressamente o devido processo legal, que só viria a aparecer em lei inglesa de 1354, durante o reinado de Eduardo III, denominada Statute of Westminster of the Liberties of London.

\footnotetext{
${ }^{6}$ PEREIRA, Ruitemberg Nunes. O princípio do devido processo legal substantivo. Rio de Janeiro: Renovar, 2005. p. 20.

${ }^{7}$ HOYOS, Arturo. La garantia constitucional del debido proceso legal. Revista de Processo, ano XII, n. 47, pp. 43-91, jul.-set. 1987. p. 45.

${ }^{8}$ NERY JUNIOR, Nelson. Princípios do processo civil na Constituição Federal. 3. ed. rev. e aum. São Paulo: Revista dos Tribunais, 1996. (Coleção estudos de direito de processo Enrico Tullio Liebman; v. 21). p. 29.
} 
Semelhante observação nos é oferecida por Marco Aurélio Gonçalves Ferreira? .

A expressão original law of the land (em latim, per legem terrae) aparece no art. 39 da Magna Carta, em que sobressai o objetivo primordial de estabelecer limites à atuação do soberano; no caso, em garantia aos privilégios dos barões feudais que se sentiam ameaçados por João Sem Terra, in verbis:

Art. 39. Nenhum homem livre será detido ou sujeito a prisão, ou privado dos seus bens, ou colocado fora da lei, o exilado, ou de qualquer modo molestado, e nós não procederemos nem mandaremos proceder contra ele senão mediante um julgamento regular pelos seus pares ou de harmonia com a lei do país. ${ }^{10}$

Vincenzo Vigoriti ${ }^{11}$ assinala que o art. 39 da Magna Carta é, nos dias de hoje, considerado, sem hesitação, o precedente direto da cláusula do due process of law da Constituição Norte-Americana - e por conseqüência, dos demais textos constitucionais que nela buscaram inspiração.

Esta opinião é compartilhada também por Letícia de Campos Velho Martel ${ }^{12}$, para quem há duas importantes etapas da história constitucional inglesa, em relação ao presente tema. A primeira está centrada, justamente, na Magna Carta, por constituir o marco original do devido processo legal em sentido genérico.

$\mathrm{O}$ segundo momento gira em torno das contendas constitucionais inglesas do século XVII, que proporcionaram uma releitura das cláusulas law of the land e due process of law, proporcionando o surgimento da versão substantiva do devido processo legal.

9 FERREIRA, Marco Aurélio Gonçalves. O devido processo legal: um estudo comparado. Rio de Janeiro: Lumen Juris, 2004. p. 15.

${ }^{10}$ MIRANDA, Jorge. Textos históricos do direito constitucional. Lisboa: Imprensa Nacional-Casa da Moeda, 1990. p. 15.

${ }^{11}$ VIGORITI, Vincenzo. Garanzie costituzionali del processo civile: due process of law e art. 24 cost. Milano: Dott. A. Giuffrè Editore, 1970. p. 25.

12 MARTEL, Letícia de Campos Velho. Devido processo legal substantivo: razão abstrata, função e características de aplicabilidade - a linha decisória da Suprema Corte estadunidense. Rio de Janeiro: Lumen Juris, 2005. p. 2-3. 
Geraldo Brindeiro ${ }^{13}$ também situa a Magna Carta como o marco inaugural do devido processo legal, na expressão original em latim by the lawful judgement of his equals or by the law of the land.

Disso não destoa Adhemar Ferreira Maciel $^{14}$, para quem o devido processo legal propagou-se no direito anglo-saxão por intermédio dos comentários de Sir Edward Coke ao art. 39 da Magna Carta Libertatum.

A Magna Carta de 1215 é, portanto, acolhida por expressiva maioria da doutrina como marco original do devido processo legal.

Estabelecida essa premissa, cabe pontuar o contexto histórico em que surgiu a Magna Carta, para que se possa ter uma ideia mais precisa dos seus fundamentos e propósitos.

Havia, na ocasião, circunstâncias políticas, econômicas e sociais que facilitaram o surgimento de algo que era inusitado para a época, no caso, o controle do poder monárquico através de limites reivindicados por um segmento do corpo social, ainda que representativo de elitizada parcela da sociedade.

Marco Aurélio Gonçalves Ferreira ${ }^{15}$ relata que o sistema jurídico inglês (common law) começou a ser traçado no reinado de Henrique II, no século XII, com o estabelecimento da jurisdição real nos assuntos penais e civis, que antes estavam sujeitos à jurisdição dos senhores feudais.

Os barões, descontentes com progressivas restrições aos seus poderes e privilégios, entregaram a João Sem Terra, filho e sucessor de Henrique II, uma carta em que reivindicavam o reconhecimento de alguns direitos em face do estado. Depois de intensas pressões, as reivindicações viriam a ser formalizadas na Magna Carta Libertatum, em 15 de junho de 1215 .

13 BRINDEIRO, Geraldo. Jurisdição constitucional e o devido processo legal. In: SAMPAIO, José Adércio Leite (Coord.). Jurisdição constitucional e direitos fundamentais. Belo Horizonte: Del Rey, 2003. p. 425.

${ }^{14}$ MACIEL, Adhemar Ferreira. Due process of law. Informativo Jurídico da Biblioteca Ministro Oscar Saraiva, v. 6, n. 2, pp. 81-88, jul. 94. p. 84.

${ }^{15}$ FERREIRA, Marco Aurélio Gonçalves. O devido processo legal: um estudo comparado. Rio de Janeiro: Lumen Juris, 2004. p. 12-15. 
Letícia de Campos Velho Martel ${ }^{16}$ observa que a Magna Carta se forjou em conjuntura que tinha como principais características: uma monarquia forte e centralizada; um sistema jurídico nacional unificado e separado dos tribunais eclesiásticos; uma classe média participante nos negócios públicos; a imposição de limites ao poder real mediante cartas de bom governo e respeito aos direitos dos súditos e as arbitrariedades e abusos do Rei João Sem Terra.

Segundo essa autora, embora os barões feudais não estivessem imbuídos de ideais democráticos e universais, pois lhes interessava apenas o resgate de poder, riquezas e privilégios, a Magna Carta acabou tendo um significado que ultrapassou aquelas intenções, transformando-se em objeto de reverência como marco inicial do movimento do constitucionalismo, sobretudo pela fixação de limites jurídicos ao absolutismo monárquico.

Vigoriti igualmente observa que, não obstante os objetivos reacionários que permearam aquele documento histórico, não há como deixar de reconhecer o admirável aspecto de que, pela primeira vez, houve o reconhecimento do princípio da supremacia da lei sobre os poderes reais, da prevalência do Estado de Direito sobre a monarquia absoluta e da imposição de limites a quem detém o monopólio da força ${ }^{17}$.

Isso não significa que somente a partir desse ponto houve o estabelecimento de um ideário acerca de direitos e proteções do corpo social, pois, conforme ressalta Couture ${ }^{18}$, o direito de defesa sempre existiu no direito clássico, mas, com a Magna Carta, adquiriu significação de ordem política e constituiu o apotegma da liberdade civil.

Nos séculos seguintes, a Magna Carta seria reafirmada cerca de 30 vezes por monarcas ingleses, a primeira delas já em 1216, por HENRIQUE III, que sucedeu JOÃO SEM TERRA depois da sua morte.

A expressão due process of law aparecerá pela primeira vez em 1354, quando a Magna Carta é expedida por EDUARDO III, desta feita adotando-se o idioma inglês. Voltará a figurar no Petition of Right (1627)

\footnotetext{
16 MARTEL, Letícia de Campos Velho. Devido processo legal substantivo: razão abstrata, função e características de aplicabilidade - a linha decisória da Suprema Corte estadunidense. Rio de Janeiro: Lumen Juris, 2005. p. 03 e ss.

17 VIGORITI, Vincenzo. Garanzie costituzionali del processo civile: due process of law e art. 24 cost. Milano: Dott. A. Giuffrè Editore, 1970. p. 25 e 26.

${ }^{18}$ COUTURE, Eduardo J. Fundamentos del derecho procesal civil. 3. ed. Buenos Aires: Ediciones Depalma, 1993. p. 98-100.
} 
e no Habeas Corpus Act (1640), quando havia forte ascendência política e jurídica de Sir Edward Coke ${ }^{19}$, eminente jurista britânico, que viria a influenciar profundamente os futuros legisladores e também os constituintes dos Estados Unidos da América ${ }^{20}$.

\subsection{MANIFESTAÇÕES NO DIREITO ESTRANGEIRO}

A influência do princípio do devido processo legal se fez sentir e desenvolver, sobretudo, no direito norte-americano, sem embargo da sua consagração também em outros sistemas jurídicos, como no direito brasileiro.

Conforme assinala Arturo Hoyos ${ }^{21}$, o traço principal da Magna Carta é o fato dela ter sido o marco inicial da positivação dos direitos fundamentais. Destinada, inicialmente, aos integrantes da nobreza, evoluiu, posteriormente, do plano contratual para o âmbito do direito público, na medida em que foi dissolvido o feudalismo e surgiram instituições representativas da soberania popular, como os parlamentos, até desembocar no constitucionalismo, quando a garantia do devido processo legal é reconhecida como um direito fundamental, cuja titularidade não mais se limita aos membros de um estamento feudal. Esse direito, pois, passa a pertencer a todo e qualquer cidadão do estado, uma conquista de caráter universal.

A Constituição Norte-Americana, a princípio, nada previa acerca desta importante garantia. Somente com o advento das primeiras dez emendas à Constituição Americana, ratificadas em 15 de dezembro de 1791 e conhecidas como Carta de Direitos (Bill of Rights), é que foram acrescidos os dispositivos que compreendiam direitos dos cidadãos americanos.

Entre esses direitos destaca-se o due process of law, previsto na Quinta Emenda, na qual se lê que nenhuma pessoa será privada de sua vida, liberdade ou propriedade sem o devido processo legal ${ }^{22}$.

19 HOYOS, Arturo. La garantia constitucional del debido proceso legal. Revista de Processo, ano XII, n. 47, pp. 43-91, jul.-set. 1987. p. 46.

${ }^{20}$ Vide nota 13.

${ }^{21}$ Ibidem. p. 47 e ss.

${ }^{22}$ Texto original, em inglês: No person shall be (...) deprived of life, liberty, or property, without due process of law... 
Posteriormente, em 09 de julho de 1868, foi ratificada a Décima-Quarta Emenda, cuja Seção 1 estendeu a qualquer pessoa nascida ou naturalizada norte-americana o direito ao devido processo legal ${ }^{23}$.

De acordo com Lawrence M. Friedman ${ }^{24}$, a sangrenta Guerra Civil (1860-1865) foi um marco divisório na história jurídica americana, tendo funcionado como um elemento catalisador de mudanças que anunciavam a passagem de uma sociedade agrícola para outra industrial e tecnológica, com o conseqüente declínio do sistema rural escravocrata.

Embora a guerra tivesse colocado fim à escravidão, muitos estados do sul dos EUA mantiveram a segregação racial e cunharam leis redutoras dos direitos da população negra, o que levou à ratificação de mais três emendas à Constituição $\left(13^{\mathrm{a}}, 14^{\mathrm{a}}\right.$ e $\left.15^{\mathrm{a}}\right)$, na tentativa de eliminar qualquer tipo de discriminação contra aquela classe de cidadãos.

Tais Emendas, como diz o apontado autor, constituíram poderosos instrumentos na busca da igualdade racial, mas, tiveram sua força amainada pela interpretação complacente dos tribunais e muito ainda haveria de ser feito, na centúria seguinte, para que a igualdade fosse efetivamente alcançada.

De qualquer modo, após a previsão do devido processo legal na Constituição Americana, ele se expandiu para diversas constituições da Europa e da América, além de ter sido acolhida por diversas convenções internacionais, como o art. 10 da Declaração Universal dos Direitos do Homem ${ }^{25}$.

Segundo Arturo $\operatorname{Hoyos}^{26}$, o princípio do devido processo legal foi encampando, de uma forma ou de outra, nos seguintes textos constitucionais da Europa Ocidental: a) art. 24 da Constituição Italiana de 1947; b) art. 103, Seção I, da Lei Fundamental da Alemanha de 1948; c) art. 24 da Constituição Espanhola de 1978.

\footnotetext{
${ }^{23}$ No original, em inglês: "All persons born or naturalized in the United States and subject to the jurisdiction thereof, are citizens of the United States and of the State wherein they reside. No State shall make or enforce any law which shall abridge the privileges or immunities of citizens of the United Sates; nor shall any State deprive any person of life, liberty, or property, without due process of law (grifo nosso); nor deny to any person within its jurisdiction the equal protection of the laws".

${ }^{24}$ FRIEDMAN, Lawrence Meir. American law: an introduction. Revised and updated. New York-London: W. W. Norton \& Company, 1997. p. 71.

${ }^{25}$ HOYOS, Arturo. La garantia constitucional del debido proceso legal. Revista de Processo, ano XII, n. 47, pp. 43-91, jul.-set. 1987. p. 47.

${ }^{26}$ Ibidem. p. 55-62.
} 
Diz aquele autor que a Constituição Francesa de 1958 não consagra expressamente o devido processo legal, mas, não obstante isso, o Counseil Constitutionnel reconheceu, em diversas decisões, algumas garantias processuais que as leis ordinárias devem respeitar.

Acrescenta que embora a Grã-Bretanha não possua uma declaração formal de direitos fundamentais e nem admita o judicial review, uma série de decisões e instituições importantes, como o julgamento por jurados, proporciona às partes garantias processuais adequadas, como a equidade, imparcialidade e independência judiciais, entre outras.

\subsection{PRESENÇA NO DIREITO BRASILEIRO}

No Brasil, o princípio do devido processo legal só foi expressamente adotado com a Constituição Federal de $1988^{27}$, sob a fórmula "ninguém será privado da liberdade ou de seus bens sem o devido processo legal" (art. 5 , LIV).

Não obstante, Letícia de Campos Velho Martel ${ }^{28}$ entende que já havia traços deste princípio no direito pátrio, pois desde as primeiras décadas do constitucionalismo republicano ele era objeto de estudo doutrinário e de aplicação pelos tribunais, principalmente por meio de seus subprincípios, como o contraditório e a ampla defesa.

Todavia, os tratados e julgamentos giravam exclusivamente em torno do caráter procedimental do devido processo legal, o que perdurou até a década de 1980.

Luiz Rodrigues Wambier ${ }^{29}$ também assinala a existência de alguns antecedentes do princípio, como o art. $141, \S 4^{\circ}$, da Constituição de 1946. Esse prescrevia que nenhuma lesão ao direito de qualquer cidadão poderia deixar de ser apreciada pelo Poder Judiciário, enunciado que apa-

27 BRINDEIRO, Geraldo. Jurisdição constitucional e o devido processo legal. In: SAMPAIO, José Adércio Leite (Coord.). Jurisdição constitucional e direitos fundamentais. Belo Horizonte: Del Rey, 2003. p. 427.

28 MARTEL, Letícia de Campos Velho. Devido processo legal substantivo: razão abstrata, função e características de aplicabilidade - a linha decisória da Suprema Corte estadunidense. Rio de Janeiro: Lumen Juris, 2005. p. 25.

${ }^{29}$ WAMBIER, Luis Rodrigues. Anotações sobre o princípio do devido processo legal. Revista dos Tribunais, São Paulo, v. 646, p. 33-40, ago. 1989. p. 37-38. 
receu também nos textos constitucionais de 1967 (art. 150, § 4º e 1969 (art. 154, § $4^{\circ}$ ).

Roberto Rosas ${ }^{30}$ entende que a Constituição de 1824 apenas tracejou o devido processo legal quando assegurou as garantias no processo (art. 179), não obstante o princípio já existisse no direito norte-americano. Atribui essa ausência à forte influência francesa em nosso direito imperial, o que somente veio a se abrandar com a Constituição Republicana de 1891.

Ao referir-se à Carta de 1891, diz que ela assegurava a plena defesa, no processo criminal, e proibia a prisão sem prévia formação de culpa (art. 72, § 14), passando in albis, novamente, em relação ao due process of law, o que seria explicado pelo fato de sermos, naquele momento, menos judiciaristas do que a doutrina e a jurisprudência norteamericana, que se abeberavam na construction da Corte Suprema em relação à larguísssima cláusula.

Roberto Rosas afirma, ainda, que, desde 1824, todas as Constituições brasileiras cuidaram de garantias processuais penais, mas sem ênfases às garantias civis, o que se devia ao fato de nossos doutrinadores, exceção feita a Rui Barbosa, terem maior interesse pelos direitos francês e italiano, em detrimento do direito americano, em que pese nossa Constituição de 1891 ter se inspirado no modelo constitucional dos EUA.

A despeito disso, cita diversos autores que, antes mesmo da Constituição de 1988, já buscavam o reconhecimento do devido processo legal em nosso direito, como Lúcio Bittencourt, José Frederico Marques, Santiago Dantas, Antônio Roberto Sampaio Dória e outros mais.

\section{FUNÇÕES DO DEVIDO PROCESSO LEGAL}

\subsection{GARANTIA DE DIREITOS FUNDAMENTAIS}

É possível identificar, na complexidade do devido processo legal, algumas funções que lhe são inerentes.

\footnotetext{
${ }^{30}$ ROSAS, Roberto. Devido processo legal: a inserção no Brasil. Revista do Advogado, ano XXIII, n. 73, nov. 2003. p. 175-177.
} 
Uma delas é servir como ponto de apoio à afirmação dos direitos fundamentais, em geral, nos casos em que o reconhecimento desses direitos dependa de profunda atividade interpretativa dos órgãos administrativos e jurisdicionais. Essa atuação afirmativa decorre da componente ética e política do devido processo legal e da sua essência axiológica, intimamente relacionada com a noção do justo.

O direito norte-americano é pródigo em casos judiciais nos quais o reconhecimento de direitos individuais ou as limitações do poder estatal se deram com base no devido processo legal.

Conforme assevera Nelson Nery Junior ${ }^{31}$, o due process of law, em seu sentido genérico, caracteriza-se pelo trinômio vida-liberdadepropriedade, ou seja, serve à tutela daqueles bens da vida, em seu sentido mais amplo e genérico, de modo que tudo o que disser respeito a isso está sob a proteção da cláusula garantidora.

Nesse contexto, cita alguns paradigmas: Meyer v. Nebraska (1923) e Pierce v. Society of Sisters (1925).

Temos que as garantias constitucionais, apesar de formarem um sistema e de todas buscarem a proteção da cidadania, frequentemente se encontram em aparente conflito, como no antagonismo da liberdade de informação com a privacidade da pessoa (informação x privacidade).

Outra situação em que se pode encontrar esse antagonismo é o direito à celeridade processual em contraposição ao contraditório e à ampla defesa, quando a tutela de urgência é prestada pelo juiz sem a prévia ciência da parte requerida.

Como nessas situações, muitas outras podem exigir do intérprete que aprofunde seu discernimento para encontrar a solução que pareça mais adequada ao direito e às circunstâncias.

Embora não seja critério hermenêutico único, o devido processo legal pode atuar como orientação às decisões judiciais e administrativas porque funciona como elemento de integração e sistematização, de forma a preservar todas as garantias constitucionais, ainda que não seja possível a atuação plena e simultânea de todas elas.

\footnotetext{
${ }^{31}$ NERY JUNIOR, Nelson. Princípios do processo civil na Constituição Federal. 3. ed. rev. e aum. São Paulo: Revista dos Tribunais, 1996. (Coleção estudos de direito de processo Enrico Tullio Liebman; v. 21). p. 31.
} 
Por sua natureza axiológica e geral, adaptável às necessidades e transformações sociais, o devido processo legal encerra as ideias de equilíbrio e permanência, a que devem coerência todas as demais garantias.

Assim, a sistematicidade e harmonia do plexo de garantias encontrará no devido processo legal um importante ponto de apoio, pois nele se encontra a essência do que buscam todas elas.

\subsection{LEGITIMAÇÃO DAS DECISÕES DO ESTADO}

Arturo Hoyos ${ }^{32}$, com muita propriedade, diz que o princípio do devido processo legal está muito ligado ao conceito de legitimidade do poder estatal.

Por legitimidade, ele entende a aptidão de uma sociedade em geral ou de um grupo obedecer a uma ordem de governo, sendo tanto maior a legitimidade quanto maior for a adesão da coletividade a esta ordem. O grau de obediência será alto quando for legítimo um regime ou uma ordem, isto é, quando as pessoas chamadas a obedecer sintam uma razão moral ou social para obedecer, ainda que contra os seus próprios interesses.

Ancorando-se em Max Weber, diz Arturo Hoyos que há três princípios de legitimação do poder: o tradicional, o racional-legal e o carismático. O primeiro põe ênfase na sabedoria do passado. O segundo tem sua máxima expressão na legalidade. O carisma cria uma lealdade emocional entre o líder e sua massa de seguidores.

O referido autor afirma que, no Estado Moderno, em vista do fato de que a burocracia depende de objetivos externamente fixados, a liderança política deve apoiar-se nas propriedades carismáticas dos indivíduos que encabeçam as organizações partidárias, e nela nenhuma dominação é puramente legal-racional.

Fazendo referência à teoria de N. Luhmann - segundo a qual os critérios de procedimento substituem os critérios materiais, ou seja, uma legitimação através do procedimento, mediante o reconhecimento geral das decisões adotadas em um determinado procedimento jurídico -, ARTURO HOYOS diz que existe a necessidade de recorrer a critérios materiais

${ }^{32}$ HOYOS, Arturo. La garantia constitucional del debido proceso legal. Revista de Processo, ano XII, n. 47, pp. 43-91, jul.-set. 1987. p. 49-50. 
de legitimação, como a idéia de justiça, pois que o procedimento formal, por si só, não é bastante para definir o conteúdo adequado de uma decisão.

No entanto, reconhece que o critério de legitimação formal, constituído por certas garantias de ordem processual, embora não seja suficiente, exerce um papel de grande transcendência na legitimação de uma dada forma de estado.

Podemos concluir que o princípio do devido processo legal, com as garantias e ideias que lhe são inerentes, tem importante função legitimadora das decisões estatais, administrativas ou judiciais, embora seja insuficiente para garantir o seu acerto ou a sua justiça.

\subsection{ORIENTAÇÃO NA CONSECUÇÃO DOS FINS SOCIAIS E COLETIVOS CONSTITUCIONALMENTE PROCLAMADOS}

Outra função do princípio do devido processo legal, dentro de um sistema jurídico, ainda segundo Arturo Hoyos ${ }^{33}$, é o "de servir como uma dimensão axiológica ou de valores como postulados éticos que devem inspirar todo o ordenamento jurídico".

Nesse caso, no que diz respeito à interpretação dos direitos fundamentais, rejeita tanto a teoria positivista como a naturalista. A primeira, por seu excessivo formalismo. A segunda, porque pode desembocar numa interpretação casuística e arbitrária dos valores que, em um certo momento, podem extrair-se, de acordo com o que cada juiz entenda que é o direito natural.

Adota, pois, a teoria da instituição, como formulada pelo professor Peter Haberle, segundo o qual, no Estado Social de Direito, os direitos sociais possuem dupla função: garantia da liberdade individual e uma dimensão institucional a partir da qual seu conteúdo deve funcionar para a consecução dos fins sociais e coletivos constitucionalmente proclamados.

Assim, os direitos fundamentais constituem direitos subjetivos, mas também são elementos fundamentais de uma ordem objetiva da co-

\footnotetext{
${ }^{33}$ HOYOS, Arturo. La garantia constitucional del debido proceso legal. Revista de Processo, ano XII, n. 47, pp. 43-91, jul.-set. 1987. p. 63-66.
} 
munidade, enquanto ela se configura como marco de uma convivência humana que encontra seu marco jurídico na constituição política.

A partir do momento em que se entende a garantia constitucional do devido processo legal como uma instituição, deve ser elucidada a sua essência, o que se faz através da identificação dos elementos desta garantia e dos interesses por ela protegidos, de forma a que qualquer limitação legal, administrativa ou judicial que, na prática, torne estes interesses impraticáveis ou se lhe negue proteção razoável, deve ser considerada como contrária à norma constitucional respectiva.

Nesse diapasão, Arturo Hoyos entende que a garantia do devido processo legal é uma instituição instrumental por meio da qual se deve assegurar às partes, no processo, oportunidades razoáveis de serem ouvidas por um tribunal competente, previsto em lei, independente e imparcial, bem como de produzir provas lícitas relacionadas com o objeto do processo e de contradizer aquelas produzidas pela outra parte, além de fazer uso dos meios legais de impugnação das decisões.

Diz, em suma, que a noção de instituição advém do fato de que o devido processo legal constitui uma idéia comum, complexa e objetiva - integrada em um todo unitário que é a Constituição - à qual aderem as vontades dos jurisdicionados, para que o estado, no exercício da função jurisdicional, lhes ofereça a tutela judicial que permita a defesa e o gozo efetivo dos direitos.

\section{$3 \quad$ PRESSUPOSTOS DO DEVIDO PROCESSO LEGAL}

\subsection{O ESTADO DEMOCRÁTICO DE DIREITO}

O princípio do devido processo legal, desde a sua origem, representou o estabelecimento de limites legais ao poder estatal e a submissão do soberano às leis do reino.

Trata-se, pois, de resolver adequadamente a tensão existente entre o exercício da autoridade e a preservação da liberdade.

Em sua evolução, passando pela confirmação da Magna Carta por Eduardo III (1354), pela Petition of Rights (1627), pelo Habeas Corpus Act (1640) e pelas Quinta e Décima-Quarta Emendas à Constituição 
Norte-Americana (1791 e 1868, respectivamente), o devido processo legal sublimou-se como garantia dos cidadãos a um processo justo, sempre que houver o risco de serem privados de sua liberdade e de sua propriedade.

Nos regimes constitucionais, isso representa mais do que a simples garantia aos procedimentos legais; simboliza a garantia, mesmo, contra leis que sacrifiquem desmesuradamente a liberdade ou a propriedade dos cidadãos, abrindo espaço para a sua invalidação através do judicial review.

Noutras palavras, trata-se de escudo jurídico contra eventuais arbitrariedades ou desmandos daqueles que exercem o poder estatal.

Dessa idéia extrai-se a conclusão de que o devido processo legal só pode ser efetivamente consagrado sob a égide do Estado Democrático de Direito, em que as leis, em geral, emanam de órgãos representativos do poder popular e dele haurem sua legitimidade.

Com efeito, essa garantia não faria o menor sentido nos regimes totalitários, em que os interesses individuais são sufocados e as liberdades civis ficam subjugadas à vontade dos soberanos ou dos grupos ocupantes do poder.

Segundo Pietro Lora Alarcón ${ }^{34}$, o Estado Democrático de Direito caracteriza-se pela efetividade plena da soberania popular, funcionando através de órgãos distintos, interdependentes e submetidos ao império da lei, para consolidar a democracia e o reconhecimento da igualdade, da dignidade e dos direitos e liberdades fundamentais da pessoa humana, o que supõe uma formulação de Justiça, que lhe é imprescindível e inerente.

Pode-se dizer, destarte, que o devido processo legal somente pode vicejar onde haja a proteção da liberdade dos cidadãos.

Sobre o significado de liberdade, conforme simbolizado pela Magna Carta, Roscoe Pound diz que não se trata daquela idéia kantiana de liberdade - a livre afirmação de si mesmo para cada um -, mas na reserva, para o indivíduo, de certas expectativas fundamentais razoáveis, in verbis:

Seja qual for atualmente o significado da palavra 'liberdade', a que nos garante a nossa declaração de

${ }^{34}$ ALARCÓN, Pietro Lora. Processo, igualdade e justiça. Revista Brasileira de Direito Constitucional, n. 2, pp. 165-198, jul.-dez. 2003. p. 176. 
direitos consiste na reserva, para o indivíduo, de certas expectativas fundamentais razoáveis que entendem com a vida na sociedade civilizada e liberação em relação ao exercício arbitrário e desarrazoado do poder e da autoridade por parte daqueles que são nomeados ou escolhidos em sociedade politicamente organizada com o objetivo de ajustar relações e ordenar a conduta e se tornam, dessa maneira, capazes de aplicar a força dessa sociedade aos indivíduos. A liberdade sob a lei implica em aplicação sistemática e ordenada de tal força, de sorte que seja uniforme, igual e previsível, resultando da razão e baseando-se em fundamentos compreensíveis mais do que no capricho ou impulso ou deixando de ouvir inteira e imparcialmente a todos quantos por ela venham a ser afetados, bem como em compreensão dos fatos que justifiquem uma ação oficial. ${ }^{35}$

Trata-se, portanto, segundo Pound ${ }^{36}$, de preservar o patrimônio hereditário da liberdade, através dos séculos, devido à exigência de equilíbrio entre os dispõem da força da sociedade organizada e os indivíduos que lhes estão sujeitos à autoridade.

\section{$3.2 \quad$ O JUDICIAL REVIEW}

Outro pressuposto para a existência do devido processo legal é a possibilidade do judicial review no sistema jurídico em que ele deve encontrar aplicação.

Não haveria sentido em invocar essa garantia se os atos dos Poderes Executivo e Legislativo não estivessem sujeitos ao crivo de validade pelo Poder Judiciário.

É por tal razão que não se pode reconhecer esse princípio, em sua inteireza, no direito inglês, posto que ali prevalece a vontade do Par-

35 POUND, Roscoe. Liberdade e garantias constitucionais. Tradução de E. Jacy Monteiro. 2. ed. São Paulo: Ibrasa, 1976. Título original: The development of Constitutional Guarantees of Liberty. p. 5.

${ }^{36}$ Ibidem. 
lamento, o qual, segundo Walter Bagehot, citado por Adhemar Ferreira Maciel $^{37}$, "podia tudo, menos transformar homem em mulher e viceversa".

Nos EUA, ao contrário, o princípio foi levado ao seu ápice, possibilitado por históricas decisões da Suprema Corte, em que se destaca o famoso caso Marbury v. Madson (1803), quando ficou reconhecida a possibilidade da revisão judicial de atos dos demais Poderes.

Geraldo Brindeiro ${ }^{38}$ anota que antes mesmo da Convenção da Filadélfia (1787), que deu origem à Constituição americana, nos Federalist Papers, Alexander Hamilton observava a importância da jurisdição constitucional, demonstrando que isso seria necessário para lhe dar efetividade, hipótese em que o Judiciário, por ser o 'menos perigoso dos poderes', ficou com a responsabilidade de assegurar os direitos fundamentais aos cidadãos.

Vincenzo Vigoriti ${ }^{39}$ observa que nos Estados Unidos vige o método difuso de controle da constitucionalidade, segundo o qual cabe a todos os juízes o poder de não aplicar, no caso concreto, a norma considerada inconstitucional.

Mais à frente, assinala que a evolução da interpretação da lex terrae - de garantia ao respeito de privilégios feudais à garantia da prevalência da própria common law, em que houve a participação decisiva de COKE (séc. XVII) e Blackstone (séc. XVIII) - contém um problema político e constitucional, pois Coke sustenta a primazia da Magna Carta sobre todos os poderes estatais, como um documento vivo e atual que, sufragando as mais importantes garantias então vigentes, tornavam ilegítimas e arbitrárias as pretensões do soberano ${ }^{40}$.

Tais circunstâncias fazem aumentar a importância do Poder Judiciário como órgão encarregado de fazer valer e tornar eficazes as garantias e direitos individuais, tarefa que foi sublimemente assumida pela Corte Suprema dos EUA.

\footnotetext{
${ }^{37}$ MACIEL, Adhemar Ferreira. Due process of law. Informativo Jurídico da Biblioteca Ministro Oscar Saraiva, v. 6, n. 2, pp. 81-88, jul. 94. p. 86.

38 BRINDEIRO, Geraldo. Jurisdição constitucional e o devido processo legal. In: SAMPAIO, José Adércio Leite (Coord.). Jurisdição constitucional e direitos fundamentais. Belo Horizonte: Del Rey, 2003. p. 423.

${ }^{39}$ VIGORITI, Vincenzo. Garanzie costituzionali del processo civile: due process of law e art. 24 cost. Milano: Dott. A. Giuffrè Editore, 1970. p. 10 e ss.

${ }^{40}$ Ibidem. p. 28-29.
} 
De fato, conforme assinala Nelson Nery Junior ${ }^{41}$, o direito constitucional, no sistema da common law, desfruta de grande reputação, sobretudo quanto à respeitabilidade e eficácia da incidência dos preceitos inscritos naquele sistema jurídico, em grande parte creditados à firme atuação da Suprema Corte dos Estados Unidos, desde que entrou em vigor a Carta da Filadélfia (1787), especialmente no que diz respeito à interpretação da cláusula due process of law.

\subsection{OS PRINCÍPIOS DA PROPORCIONALIDADE OU RAZOABILIDADE}

Também atuam como condicionantes do devido processo legal os conhecidos princípios da proporcionalidade ou da razoabilidade, já que sua aplicação se dá em situações diversificadas e cambiantes, que exigem, em cada caso concreto, a análise da adequação dos atos de autoridade ou das normas legais, conforme os fins que são perseguidos por eles.

Roberto $\operatorname{Rosas}^{42}$ afirma que os princípios da proporcionalidade e da razoabilidade são formadores essenciais do devido processo legal, mas diz que há distinção entre eles, sendo que a razoabilidade está mais presente nos Estados Unidos, enquanto a proporcionalidade é mais intensa na Europa.

Explica aquele autor, que na linguagem jurídica americana a palavra reasonable tem o sentido de algo que é adequado, plausível, considerável, imparcial, justificável, e reasonableness como senso comum, eqüidade, justiça, moderação (William C. Burton, Legal thesaurus), ou então, racional, não arbitrário ou caprichoso (Ballentine`s).

Segundo diz, o homem é animal razoável com meios e fins, e a liberdade para o exame da razoabilidade da lei ou de uma decisão não pode tomar o rumo daquilo que ROBERT BORK chamou de sedução política do Direito. Citando Perelman, lembra que há limite à tolerância e que inaceitável é o desarrazoado.

\footnotetext{
${ }^{41}$ NERY JUNIOR, Nelson. Princípios do processo civil na Constituição Federal. 3. ed. rev. e aum. São Paulo: Revista dos Tribunais, 1996. (Coleção estudos de direito de processo Enrico Tullio Liebman; v. 21). p. 32-33.

42 ROSAS, Roberto. Devido processo legal: proporcionalidade e razoabilidade. Revista dos Tribunais, São Paulo, ano 90, v. 783, jan. 2001. p. 11-15.
} 
Sobre o princípio da proporcionalidade, conhecido como proibição do excesso, diz que também pode ser entendido com princípio do Estado de Direito, ou direito fundamental, que vai desdobrar-se em diversos aspectos ou requisitos.

Por este princípio, a solução adotada para a efetivação de um ato ou de uma medida deve ser adequada a seu fim ou fins, valendo tanto para atos discricionários como para atos vinculados.

Pode, ainda, ser invocado no exame da finalidade das leis, como restrição à regra da liberdade do legislador.

Salienta que o homem é objeto de proteção do Estado e a subsunção dos seus interesses ao interesse público ou coletivo somente pode ser admitida quando não haja outra forma menos prejudicial de atuação estatal. É indispensável, pois, a demonstração da necessidade material que justifique o ato, numa dimensão temporal e espacial, circunscrevendo-se aos grupos ou pessoas aos quais se imponha aquela necessidade.

No caso, os elementos integradores da proporcionalidade seriam: a) a adequação entre o meio e fim do ato legislativo ou administrativo; b) a necessidade decorrente da exigência indispensável do ato, impondo-se o mais suave ou menos oneroso; c) a relação custo-benefício do ato, inclusive no que diz respeito ao cotejo entre dois direitos fundamentais (liberdade v. interesse público; liberdade v. proteção individual).

Ocorrerá a inconstitucionalidade quando houver desproporção entre os fins programáticos e as demais regras constitucionais.

Ressalta, ainda, citando Konrad Hesse, que, na relação entre concessões e restrições à liberdade, sempre haverá uma presunção inicial a favor da liberdade.

Conclui seu raciocínio, argumentando que o critério da razoabilidade é agente limitador do poder normativo estatal, pois a infringe o devido processo legal se faz diferenças ou classificações arbitrárias ou tendenciosas.

Portanto, a aferição da proporcionalidade e da razoabilidade dáse segundo a lei determinadora da restrição de direitos.

Gisele Santos Fernandes Góes ${ }^{43}$, também apresenta o devido processo legal como fundamento do princípio da proporcionalidade.

\footnotetext{
${ }^{43}$ GÓES, Gisele Santos Fernandes. Princípio da proporcionalidade no processo civil: o poder de criatividade do juiz e o acesso à justiça. São Paulo: Saraiva, 2004. p. 74.
} 


\section{ACEPÇÕES DO DEVIDO PROCESSO LEGAL}

\subsection{DEVIDO PROCESSO LEGAL SUBSTANTIVO}

Há um arraigado vezo, no direito pátrio, de restringir o entendimento do princípio do devido processo legal ao seu aspecto puramente procedimental.

No entanto, é fato que, de garantias especificamente processuais (direito de defesa, julgamento imparcial etc), o princípio evoluiu para adquirir, também, um sentido material ou substantivo.

Conforme assevera Geraldo Brindeiro ${ }^{44}$, a cláusula do devido processo legal no Direito Constitucional americano, numa primeira fase, refere-se apenas a garantias de natureza processual (orderly proceedings) como a instrução contraditória, o direito de defesa, o duplo grau de jurisdição e a publicidade dos julgamentos. Contudo, a partir de 1890, incorporou-se o sentido de proteção substantiva dos direitos e liberdades civis assegurados no Bill of Rights (as dez primeiras emendas à Constituição Americana).

Destaca, ainda, aquele autor, que a Suprema Corte, por meio de construção jurisprudencial (construction) e baseando-se em critérios de razoabilidade (reasonableness), passou a promover a proteção dos direitos fundamentais contra ações não razoáveis e arbitrárias.

Afirma, nesse diapasão, a existência de grande quantidade de decisões na Suprema Corte americana, bem como no Brasil, contra os excessos do poder estatal, principalmente no campo processual penal, do direito de punir, do poder de punir do Estado e do poder de tributar.

Arturo Hoyos ${ }^{45}$ também chama a atenção para o fato de que não devemos perder de vista a evolução do princípio do devido processo legal, desde sua consagração na Magna Carta até sua posterior sagração nas constituições dos estados contemporâneos e nos instrumentos internacionais de proteção dos direitos humanos.

44 BRINDEIRO, Geraldo. Jurisdição constitucional e o devido processo legal. In: SAMPAIO, José Adércio Leite (Coord.). Jurisdição constitucional e direitos fundamentais. Belo Horizonte: Del Rey, 2003. p. 425-426.

45 HOYOS, Arturo. La garantia constitucional del debido proceso legal. Revista de Processo, ano XII, n. 47, pp. 43-91, jul.-set. 1987. p. 46-47. 
Assinala que, com o constitucionalismo, a garantia do devido processo legal é reconhecida como um direito fundamento e consagrada como um instrumento de direito público, cuja titularidade é de todos os cidadãos de um Estado.

Nelson Nery Junior ${ }^{46}$ também assevera que a cláusula due process of law indica mais do que a tutela processual, pois também há o substantive due process of law que indica a incidência do princípio em seu aspecto substancial, ou seja, atua no que diz respeito ao próprio direito material, tanto no âmbito judicial como administrativo.

Explica, aquele autor, que o conceito do devido processo foi sendo modificado com o tempo, através da doutrina e da jurisprudência, de forma a alargar o seu âmbito de abrangência e permitir interpretação mais ampla, em nome dos direitos fundamentais do cidadão.

Acrescenta, ainda, que o princípio manifesta-se em todos os campos do direito, em seu aspecto substancial, como no direito administrativo, em que se manifesta através do princípio da legalidade.

Ainda segundo Nery Junior, o substantive due process se originou das discussões acerca dos limites do poder de governar, submetidas à Suprema Corte americana no final do século XVIII, quando ficou assentando que o legislativo deve produzir leis que satisfaçam o interesse público, o que se traduz no princípio da razoabilidade das leis. ${ }^{47}$

Como exemplos da incidência do devido legal substantivo no direito americano, cita: a liberdade de contratar (Fletcher v Peck - 1810); a garantia do direito adquirido (vested rights doctrine); a irretroatividade da lei penal, entre outros.

Também Letícia de Campos Velho Martel ${ }^{48}$ menciona que no Direito Inglês encontra-se o antecedente histórico do devido processo legal, no qual também estão as bases do Direito Norte-Americano, podendo estar, ainda, a primeira manifestação da substantividade do devido processo legal. Anota, porém, que a versão substantiva não vingou na Inglaterra porque ali foi adotada a supremacia parlamentar, noção incom-

\footnotetext{
${ }^{46}$ NERY JUNIOR, Nelson. Princípios do processo civil na Constituição Federal. 3. ed. rev. e aum. São Paulo: Revista dos Tribunais, 1996. (Coleção estudos de direito de processo Enrico Tullio Liebman; v. 21). p. 34-38.

47 Ibidem. p. 37.

48 MARTEL, Letícia de Campos Velho. Devido processo legal substantivo: razão abstrata, função e características de aplicabilidade - a linha decisória da Suprema Corte estadunidense. Rio de Janeiro: Lumen Juris, 2005. p. 28.
} 
patível com a de controle jurisdicional de constitucionalidade, de modo que foi nos Estados Unidos que o devido processo legal substantivo tornou-se doutrina constitucionalmente aceita.

Ressalta, entretanto, que não é fácil desvendar a origem da versão substantiva do princípio e diz que sua origem é descrita como um enigma, um impasse histórico, pois não se sabe ao certo como, quando e onde a cláusula do devido processo legal foi enlaçada com o controle material de constitucionalidade, tornando-se comando hábil a autorizar as Cortes de Justiça a controlar razoabilidade do conteúdo dos atos normativos. $^{49}$

Há autores que sustentam, porém, que o caráter substantivo já se fazia presente na própria Magna Carta de 1215.

Em obra acerca do devido processo legal substantivo, RUITEMBERG NUNES PEREIRA assevera que o Direito Inglês, por sua própria estrutura, mais dotado de regras procedimentais do que de direito material, como era inerente ao Common Law, leva a pensar que a Magna Carta e suas demais cartas de direitos tinham conteúdo exclusivamente processual, o que, a seu ver, constitui um equívoco.

Segundo pensa, a par desse elemento processual, decorrente da própria estrutura e natureza do Direito Inglês, deve-se registrar também que o conceito do due process of law englobava, já na era medieval, não apenas a necessidade de observar o processo (orderly proceedings), mas também direitos de ordem material, consubstanciados nas normas do Common Law, Statute Law ou Custome of England. ${ }^{50}$

Escudado em Charles A. Miller, diz que, por influência acadêmica e política de Edward Coke, ficou mais evidente a dupla natureza material e procedimental da cláusula due process, pela revivescência que Coke imprimiu à Magna Carta, transformando-a em uma fonte de liberdades (source of liberties), expressão que pode ser considerada sinônima de direitos individuais ou fundamentais. ${ }^{51}$

Para ele, a maior demonstração de que a expressão due process of law, em sua primeira aparição na Magna Carta de 1354, já nasceu com

\footnotetext{
${ }^{49}$ MARTEL, Letícia de Campos Velho. Devido processo legal substantivo: razão abstrata, função e características de aplicabilidade - a linha decisória da Suprema Corte estadunidense. Rio de Janeiro: Lumen Juris, 2005. p. 2.

${ }^{50}$ PEREIRA, Ruitemberg Nunes. O princípio do devido processo legal substantivo. Rio de Janeiro: Renovar, 2005. p. 76-78.

${ }^{51}$ Ibidem. p. 76-78.
} 
a dúplice natureza material e processual está no fato de que o texto de Eduardo III não mais contemplava as duas expressões per legale judicium parium suorum (by the lawful judgment of his peers) - aspecto exclusivamente processual - e per legem terrae (by the law of land) - aspecto material. Postas as coisas desta forma, a expressão due process of law abarcaria tanto o aspecto material como o processual.

Aqui estaria, segundo o mesmo autor, o gérmen da dimensão substantiva do devido processo legal, que seria desenvolvida no Direito Norte-Americano.

\subsection{DEVIDO PROCESSO LEGAL PROCEDIMENTAL}

De acordo com Letícia de Campos Velho Martel, a origem da versão procedimental do devido processo legal confunde-se com a origem da própria cláusula, na figura do seu antecedente histórico (law of the land), ou seja, na Magna Carta inglesa. ${ }^{52}$

Quanto a isso, não há, realmente, divergências doutrinárias, posto que o aspecto procedimental esteve no âmago das garantias que se procurou estabelecer com a Magna Carta e demais declarações de direito que depois se sucederam.

Isso não significa que o aspecto procedimental do devido processo legal tenha conservado exatamente a mesma feição e esteja infenso a inovações. Ao contrário, como todas as instituições, também ele sofre os influxos de uma nova dinâmica social e de perspectivas diversas.

Sob este prisma, ajustam-se as palavras de Pietro Lora Alarcón ${ }^{53}$, no sentido de que há uma concepção moderna de processo, a partir do pensamento da doutrina alemã, especialmente de Oscar Von Bülow, de que há dois âmbitos da atuação processual: a) uma relação material (conflito de interesses); b) e uma relação de caráter público, pela qual o juiz está obrigado a dizer o direito em face da solicitação das partes.

52 MARTEL, Letícia de Campos Velho. Devido processo legal substantivo: razão abstrata, função e características de aplicabilidade - a linha decisória da Suprema Corte estadunidense. Rio de Janeiro: Lumen Juris, 2005. p. 2.

53 ALARCÓN, Pietro Lora. Processo, igualdade e justiça. Revista Brasileira de Direito Constitucional, n. 2, pp. 165-198, jul.-dez. 2003. p. 181-183. 
De acordo com o citado autor, a noção mais avançada de Estado Democrático de Direito caminha na via de uma noção de processo ajustada às finalidades dessa forma de estado, em que o processo reveste-se de três perfis: técnico, constitucional e teleológico.

No caso, o perfil técnico relaciona-se ao funcionamento do processo, como conjunto de procedimentos. $\mathrm{O}$ perfil constitucional refere-se à correspondência com as formas constitucionais que plasmam os caracteres do Estado Democrático do Direito. O perfil teleológico diz respeito ao modo de se amoldar o processo à finalidade de fazer valer a Justiça, baseado no respeito absoluto aos direitos e liberdades fundamentais do ser humano.

Por isso, diz Alarcón, fixar o núcleo do processo somente no procedimento é sonegar sua real relevância dentro do Estado Democrático de Direito, porque o processo, além de técnica procedimental, funciona também como medida do caráter democrático do Estado. Mais do que técnica, constitui garantia de Justiça para a coletividade, sendo informado por uma série de princípios que visam limitar a realização arbitrária do direito.

Nesse diapasão, diz que para definir o processo, no Estado Democrático de Direito, é necessário aceitar o valor nele implícito: a defesa e tutela das liberdades dos cidadãos por meio de garantias preestabelecidas, verdadeiras técnicas jurídicas, a serviço das partes e conflito, com a finalidade de uma sentença justa, hipótese em que se exige do procedimento flexibilidade para o atendimento dos interesses em conflito; certeza, para a garantia dos direitos que se questionam; fluidez e celeridade, para que seja pronta a solução ou cessação da ameaça.

Nelson Nery Junior acentua que o sentido processual da expressão devido processo legal tem significado mais restrito, sendo que, no Direito americano, significa o dever de propiciar ao litigante as seguintes prerrogativas: a) comunicação adequada sobre a recomendação ou base da ação governamental; b) um juiz imparcial; c) a oportunidade de deduzir defesa oral perante o juiz; d) a oportunidade de apresentar provas perante o juiz; e) a chance de reperguntar às testemunhas e de contrariar provas que forem utilizadas contra o litigante; f) o direito de ter um de- 
fensor no processo perante o juiz ou tribunal; g) uma decisão fundamentada, com base no que consta nos autos. ${ }^{54}$

Menciona, ainda, outras conseqüências adicionais do princípio, no direito processual americano: a) o direito a processo com a necessidade de haver provas; b) o direito de publicar-se e estabelecer-se conferência preliminar sobre as provas que serão produzidas; c) o direito a uma audiência pública; d) o direito à transcrição dos atos processuais; e) julgamento pelo tribunal do júri (civil); f) o ônus da prova, que o governo deve suportar mais acentuadamente do que o litigante individual..$^{55}$

Segundo Nery Junior, a doutrina brasileira tem empregado a locução devido processo legal unicamente nesse sentido processual, como se percebe da enumeração, v.g., que se fez das garantias delas oriundas: a) direito à citação e ao conhecimento do teor da acusação; b) direito a um rápido e público julgamento; c) direito ao arrolamento de testemunhas e à notificação das mesmas para comparecimento perante os tribunais; d) direito ao procedimento contraditório; e) direito de não ser processado, julgado ou condenado por alegada infração às leis ex post facto; f) direito à plena igualdade entre acusação e defesa; g) direito contra medidas ilegais de busca e apreensão; $h$ ) direito de não ser acusado nem condenado com base em provas ilegalmente obtidas; i) direito à assistência judiciária, inclusive gratuita; j) privilégio contra a autoincriminação.

\section{REFERÊNCIAS BIBLIOGRÁFICAS}

ALARCÓN, Pietro Lora. Processo, igualdade e justiça. Revista Brasileira de Direito Constitucional, n. 2, pp. 165-198, jul.-dez. 2003.

BRINDEIRO, Geraldo. Jurisdição constitucional e o devido processo legal. In: SAMPAIO, José Adércio Leite (Coord.). Jurisdição constitucional e direitos fundamentais. Belo Horizonte: Del Rey, 2003.

COUTURE, Eduardo J. Fundamentos del derecho procesal civil. 3. ed. Buenos Aires: Ediciones Depalma, 1993.

\footnotetext{
${ }^{54}$ NERY JUNIOR, Nelson. Princípios do processo civil na Constituição Federal. 3. ed. rev. e aum. São Paulo: Revista dos Tribunais, 1996. (Coleção estudos de direito de processo Enrico Tullio Liebman; v. 21). p. 38.

${ }^{55}$ Ibidem.
} 
FERREIRA, Marco Aurélio Gonçalves. O devido processo legal: um estudo comparado. Rio de Janeiro: Lumen Juris, 2004.

FRIEDMAN, Lawrence Meir. American law: an introduction. Revised and updated. New York-London: W. W. Norton \& Company, 1997.

GÓES, Gisele Santos Fernandes. Princípio da proporcionalidade no processo civil: o poder de criatividade do juiz e o acesso à justiça. São Paulo: Saraiva, 2004.

HOYOS, Arturo. La garantia constitucional del debido proceso legal. Revista de Processo, ano XII, n. 47, pp. 43-91, jul.-set. 1987.

MACIEL, Adhemar Ferreira. Due process of law. Informativo Jurídico da Biblioteca Ministro Oscar Saraiva, v. 6, n. 2, pp. 81-88, jul. 94.

MARTEL, Letícia de Campos Velho. Devido processo legal substantivo: razão abstrata, função e características de aplicabilidade - a linha decisória da Suprema Corte estadunidense. Rio de Janeiro: Lumen Juris, 2005.

MIRANDA, Jorge. Textos históricos do direito constitucional. Lisboa: Imprensa Nacional-Casa da Moeda, 1990.

NERY JUNIOR, Nelson. Princípios do processo civil na Constituição Federal. 3. ed. rev. e aum. São Paulo: Revista dos Tribunais, 1996. (Coleção estudos de direito de processo Enrico Tullio Liebman; v. 21)

PEREIRA, Ruitemberg Nunes. O princípio do devido processo legal substantivo. Rio de Janeiro: Renovar, 2005.

POUND, Roscoe. Liberdade e garantias constitucionais. Tradução de E. Jacy Monteiro. 2. ed. São Paulo: Ibrasa, 1976. Título original: The development of Constitutional Guarantees of Liberty.

ROSAS, Roberto. Devido processo legal: proporcionalidade e razoabilidade. Revista dos Tribunais, São Paulo, ano 90, v. 783, pp. 11-15, jan. 2001.

. Devido processo legal: a inserção no Brasil. Revista do Advogado, ano XXIII, n. 73, p. 175-177, nov. 2003.

SILVEIRA, Paulo Fernando. Devido processo legal. 3. ed. rev., atual. e ampl. Belo Horizonte: Del Rey, 2001.

VIGORITI, Vincenzo. Garanzie costituzionali del processo civile: due process of law e art. 24 cost. Milano: Dott. A. Giuffrè Editore, 1970. 
WAMBIER, Luis Rodrigues. Anotações sobre o princípio do devido processo legal. Revista dos Tribunais, São Paulo, v. 646, p. 33-40, ago. 1989. 
